\title{
Do the Patients Read the Informed Consent?
}

\author{
Mehmet Özgür Özhan ${ }^{1}$, Mehmet Anıl Süzer ${ }^{1}$, İlker Çomak², Ceyda Özhan Çaparlar³, Gözde Bumin Aydın², \\ Mehmet Burak Eşkin ${ }^{4}$, Bülent Atik ${ }^{4}$, Atilla Ergin ${ }^{5}$, Nedim Çekmen ${ }^{6}$, Ercan Kurt ${ }^{4}$
}

\author{
${ }^{1}$ Department of Anaesthesiology and Reanimation, TDV 29 Mayıs Hospital, Ankara, Turkey \\ ${ }^{2}$ Department of Anaesthesiology and Reanimation, Diyarbakır Military Hospital, Diyarbakır, Turkey \\ ${ }^{3}$ Department of Anaesthesiology and Reanimation, Ministery of Health, Yıldırım Beyazıt Training Hospital, Ankara, Turkey \\ ${ }^{4}$ Department of Anaesthesiology and Reanimation, Gülhane Military Medical Academy, Ankara, Turkey \\ ${ }^{5}$ Department of Anaesthesiology and Reanimation, Polatlı Can Hospital, Ankara, Turkey \\ ${ }^{6}$ Department of Anaesthesiology and Reanimation, Güven Hospital, Ankara, Turkey
}

Background: Informed consent is a process which consists of informing the patient about the medical interventions planned to be applied to the patient's body and making the patient active in the decision making process.

Aims: The aim of this study was to evaluate whether the patients read the informed consent document or not and if not, to determine why they did not read it. This was achieved via a questionnaire administered at the pre-anaesthetic visit to assess the perception of patients to the informed consent process.

Study Design: Survey study.

Methods: The patients were given a questionnaire after signing the informed consent document at the pre-anaesthetic visit. We studied whether the patients read the informed consent document or not and asked for their reasons if they did not.

Results: A total of 522 patients were included during the two month study (mean age: 38.1 years; $63.8 \%$ male, $36.2 \%$ female). Overall, $54.8 \%$ of patients reported that they did not read the informed consent.
Among them, 50.3\% did not care about it because they thought they would have the operation anyway, $13.4 \%$ did not have enough time to read it, $11.9 \%$ found it difficult to understand, $5.9 \%$ could not read because they had no glasses with them, and 5.2\% found it frightening and gave up reading. Inpatients, older patients and patients with co-morbidities were less likely to read the informed consent document than outpatients, and younger and healthy patients $(\mathrm{p}<0.05)$. Also, $57.9 \%$ of parents whose children would be operated on had read the document.

Conclusion: This study shows that the majority of our patients did not understand the importance of the informed consent. It is therefore concluded that informed consent documents should be rearranged to be easily read and should be supported with visual elements such as illustrations or video presentations, as informed consent is a process rather than just simply signing a form.

(Balkan Med J 2014;31:132-6).

Key Words: Anaesthesia, informed consent, questionnaire
Informed consent (IC) is one of the keystones of medical applications and takes its source from the autonomy principle. It is a process which consists of informing the patient about the medical interventions planned to be applied to their body and making the patient active in the decision making process (1).

The doctor who undertakes the medical care is responsible for providing the requirements throughout this process. For this reason, obtaining the patient's approval after the informed consent procedure is made compulsory via legal regulations throughout the world $(2,3)$.

During the IC process, the information that the patient receives, with the help of the communication between the doctor and the patient, is given to the patient as a written informed consent document (ICD) and the process ends with the patient signing the form (4).

It has been found that the anxiety of the patients increases and they are less satisfied when they do not receive sufficient information about the medical interventions and have difficulties making decisions (5). However, there are a few studies that have investigated the reading behaviours of patients when the information is provided to them as the IC.

This study was conducted in the Gülhane Military Medical School to evaluate whether the patients read the ICD or not and if not, to determine the reasons; also, we aimed to find out the opinions of the patients about the ICD. 


\section{MATERIAL AND METHODS}

After approval of the hospital's ethics committee, this study, which lasted for two months, was conducted in the polyclinic of the anaesthesia department. In our hospital, ICD is given to the inpatients on the ward and to outpatients at the polyclinic; in both cases, they are asked to read them. Patients consulting the polyclinic are given a rotation number after they hand in their ICD and files and are called from the waiting room for an interview with the anaesthesiologist. During the interview, they are informed about the anaesthetic management, risks, and general information about the pre-anaesthesia period (fasting, whether the drugs should be taken before the operation or not, etc.) and their questions are answered. If the patient consents for the anaesthetic procedure, the IC period is completed and the patient and doctor sign the ICD.

In this study, after the ICD was signed, the patients were informed about the study and asked whether they wanted to participate. Written approval was taken from those patients who decided to join the study, and they were given a survey sheet prepared for the study. In this questionnaire, the patients were asked whether they read the ICD or not, and if not, what their reasons were. The answers were recorded as they explained. Illiterate patients, children, and those who were not able to read because of health problems were recorded and the questionnaire was given to their relatives or parents. Other information about the patients was taken from the files. After this information was recorded, similar responses to the questionnaire were grouped.

\section{Statistical analysis}

Data analysis was conducted using SPSS 16.0 for Windows (Inc., Chicago, IL, USA). Statistical analysis was evaluated by using frequency and multi-variability analysis (chi-square test and Fisher's exact test). $\mathrm{P}$ value $<0.05$ was considered statistically significant.

\section{RESULTS}

In total, 522 patients were included in this study during a two month period. The mean age of the patients was $38.1 \pm 21.6$ years (median: 35.0). The demographic data are shown in Table 1.

It was determined that 286 patients $(54.8 \%)$ did not read the ICD, while $236(45.2 \%)$ did $(p=0.032)$ (Table 2$)$. The ratio of female and male patients who read the ICD was not statistically different $(41.8 \%$ vs. $47.1 \%$, respectively $(p=0.238)$ ) (Table 2). When we studied the age groups, it was found that the rate of reading the ICD between the ages 13-34 was higher compared to other age groups, and when the age increased the rate of not reading the ICD also increased (Table 2). The rate of reading the ICD by patients with comorbidities was lower than in those without comorbidities $(37.3 \%$ vs. $49.8 \%$; $p=0.023$ ) (Table 2).

When the reasons for not reading were evaluated, it was found that $50.3 \%$ of the patients declared that they did not
TABLE 1. Demographic data

\begin{tabular}{lcc}
\hline & Number (n) & Ratio (\%) \\
\hline Female & 189 & 36.2 \\
Male & 333 & 63.8 \\
Age (mean / median; yr) & $38.1 \pm 21.6 /(35.0)$ & \\
Comorbidity & 150 & 28.8 \\
Outpatient & 430 & 82.4 \\
Inpatient & 92 & 17.6 \\
Literate & 514 & 98.5 \\
\hline
\end{tabular}

TABLE 2. The ratio of reading and not reading the Informed Consent Document according to patient characteristics and age groups

\begin{tabular}{lccc}
\hline ICD & & \\
Patient Characteristics & & Did read (\%) & Did not read (\%) \\
\hline Total & $45.2^{*}$ & $54.8^{*}$ \\
Female / Male & & $41.8 / 47.1$ & $58.2 / 52.9$ \\
Inpatient / Outpatient & & $23.9 / 49.8^{*}$ & $76.1 / 50.2^{*}$ \\
Comorbidity + / - & & $37.3 / 48.8^{*}$ & $62.7 / 51.2 *$ \\
Age groups (years) & $0-14^{* *}$ & 53.7 & 46.3 \\
& $14-34$ & 56.1 & 43.9 \\
& $35-49$ & 45.6 & 54.4 \\
& $50-64$ & 38 & 62 \\
& $>65$ & 32.3 & 67.7 \\
& Total & 45.2 & 54.8 \\
\hline
\end{tabular}

ICD: informed consent document

${ }^{*} \mathrm{p}<0.05$ : considered statistically significant

**The reading of ICDs for patients $<14$ years was requested of the parents

TABLE 3. Explanations from patients regarding reasons for not reading the Informed Consent Document

\begin{tabular}{|c|c|c|c|c|c|c|}
\hline \multirow[t]{2}{*}{ Explanation } & \multicolumn{2}{|c|}{ Total } & \multicolumn{2}{|c|}{ Outpatient } & \multicolumn{2}{|c|}{ Inpatient } \\
\hline & $\mathrm{n}$ & $\%$ & $\mathrm{n}$ & $\%$ & $\mathrm{n}$ & $\%$ \\
\hline Ignored & 144 & 50.3 & 21 & 30.0 & 123 & 57 \\
\hline Not enough time & 38 & 13.4 & 4 & 5.7 & 34 & 15.7 \\
\hline Not understand, bored & 34 & 11.9 & 9 & 12.9 & 25 & 11.6 \\
\hline Not told to read & 30 & 10.5 & 29 & 41.4 & 1 & 0.5 \\
\hline No glasses & 17 & 5.9 & 3 & 4.3 & 14 & 6.5 \\
\hline Scared, not read & 15 & 5.2 & 1 & 1.4 & 14 & 6.4 \\
\hline Illiterate & 8 & 2.8 & 3 & 4.3 & 5 & 2.3 \\
\hline Total & 286 & 100 & 70 & 100 & 216 & 100 \\
\hline
\end{tabular}

care about reading it, and that they would have the operation eventually, $13.4 \%$ said they did not have time to read because it was their turn for the interview, $11.9 \%$ stated that they did not understand the information in the ICD, got bored and gave up reading it and $10.5 \%$ declared that they were not told to read it. Also, 5.9\% did not read it because they did not have their glasses with them, and 5.2\% said they were scared by the ICD. Finally, $2.8 \%$ could not read the document because they were illiterate (Table 3 ).

The rate of not reading the ICD in the inpatient population was higher than for outpatients $(76.1 \%$ vs. $50.2 \% ; p=0.00)$. The highest rates among the reasons why they did not read it for outpatients were 'paying no attention/ignoring' (57\%) and 
'not finding time' (15.7\%); while for inpatients the reasons were 'I was not told to read' (41.4\%) and 'I was paying no attention/ignoring' (30\%) (Table 3).

\section{DISCUSSION}

The study shows that the great majority of patients consent for anaesthetic procedures without reading the ICD. While evaluating the reasons for not reading, we came to the conclusion that the patients did not understand the aim of the ICD and the IC procedure.

In the first studies about IC, which were conducted more than 20 years ago, it was aimed to determine the contribution of the IC process to informing patients and the patients' perspectives to the process. It was concluded that the majority of patients $(59 \%$ and $69 \%)$ did not read the ICD $(6,7)$ (Table 4$)$.

While evaluating the patients who did not read the ICD, we found that the rate of reading the ICD was higher in young people compared to old people, outpatients compared to inpatients and patients without comorbidities to those with comorbidities. This result is compatible with other studies in the literature $(7,8)$. Among the reasons for not reading, healthy patients' curiosity about an operation which might ruin their physical integrity and old patients' decreased reading capacity and cognitive functions were noteworthy.

A total of $5.9 \%$ of the patients stated that they did not read it because they did not have their glasses with them and some of them might have had a decrease in reading motivation because of their uneasiness of the ICD or the fact that they wanted more of a chance to communicate with the healthcare professionals who could inform them directly.

Meanwhile, the reason for inpatients' not reading the ICD included not being told to, which made us think that the healthcare professionals did not have that different an opinion of the IC process than the patients.

Not reading the ICD does not necessarily mean that the patient does not want to be informed about the medical interventions. On the contrary, as shown by the results of recent studies, the patients want to be informed, but they find the given information insufficient. The more information about the surgical interventions provided, the less anxious the patients are, and the more active a role the patients take in the medical decision making process (9).

Although ICD is an important part of the medico-legal period, the cornerstone of this period is the verbal communication between the patient and the doctor. However, it has been reported in studies that the majority of the patients do not understand or forget most of the verbal information given because of their educational level, age, a decrease in cognitive functions or anxiety.

In a study published by Krupp et al. about patients who did not have a neurological disease, it was determined that $65 \%$ of the patients did not remember more than 2 of the 6 major complications in the information given verbally about surgery and that the rate of generally recalled information was $18 \%(10)$. In another study, patients who underwent reduction mammoplasty could recall 3 complications out of 12 which they were verbally informed about (11).

In another study held in a patient population planning to have general surgical operations, it was found that 27 out of 100 patients did not know which organ would be operated on, and 44 were not even able to remember basic information about the operation (for example, in the laparoscopic cholecystectomy operation, the gall bladder is taken) (12). For this reason, ICD given as a written form is a reference source, meaning that the patients can keep the information and reread it when they forget something; also, they can ask questions about anything that they did not understand (13). In addition, it is recommended to inform the patient and to take their consent using a written form (14). In a study by Gulham et al., it was shown that the patients were more satisfied $(89 \%$ vs. $95 \%$ ) when the information was provided in written format in addition to verbal communication (15).

Nevertheless, the data obtained in studies evaluating the patients' opinion of ICD are quite variable. In two studies in which the rate of reading the ICD was low, $60 \%$ of the patients stated that ICD was a document - piece of paper - arranged to protect the hospital and the doctor and to give the initiative in the decision making process to the doctor. Another piece of information received from these patient groups was that the patients thought that signing the ICD was a legal necessity in which they handed their legal rights to the hospital and the doctor, and that if they refused to sign it, they would not have the operation; also, they thought that they could not change their minds after signing the $\operatorname{ICD}(5,16)$.

Also in our study, "paying no attention" and "not finding time" were the two most common reasons for not reading the ICD, even though in our polyclinic, patients were called in the order in which they handed in their ICD. According to these results, the reasons our patients gave for not reading the ICD indicate a perception of the ICD as just a piece of paper and a waste of time, instead of a document protecting their rights, securing their preferences and informing them. Another result supporting our opinion was that just 2 of 522 patients wanting a copy of the ICD said that they read it later.

\section{How should we increase the rate of reading ICD?}

Information on the ICD contains many technical terms, as also reported for prescription, insurance and banking papers, which the patients cannot easily understand. In a study in the USA, it was noted that the ICD is prepared for high-school (class 12) or higher education level patients, whereas the general education level of the population is primary-school level. When the intelligibility level is lowered to the level of class 5 , it is seen that the ICD is more easily understood (17). 
TABLE 4. Studies reporting the rate of not reading the Informed Consent Document

\begin{tabular}{lcccc}
\hline Therapy & Year & Location & Number of patients (n) & The rate of not reading ICD (\%) \\
\hline Oncology $^{6}$ & 1980 & USA & 200 & 59 \\
Laparoscopic cholecystectomy $^{7}$ & 1993 & England & 250 & 69 \\
Gynaecological procedures $^{5}$ & 2004 & England & 1006 & 17 \\
Endoscopy $^{8}$ & 2006 & Spain & 309 & 15 \\
Anaesthesia $^{26}$ & 2006 & Spain & 159 & 21 \\
\hline
\end{tabular}

ICD: informed consent document

Informed consent documents are generally long texts. They have to give information about at least four basic subjects: diagnosis of the disease, treatment plan, any possible complications of the treatment and alternative treatment methods. In a study by Berger et al., it was found that ICDs that have been prepared in the last 20 years are twice as long as those prepared before. The reason for this is the need to give patients more information and developments of the four subjects mentioned above $(18,19)$.

The ICD for anaesthetic procedures in our hospital consists of 1883 words and is seven pages long. The reading rate of Turkish people varies between 160 and 220 words a minute (20). Therefore, even a well-educated personality can only read this document in 8.3-11.4 minutes. In addition, it is not difficult to predict that high levels of noise (although the general level of noise is 35 decibels, the noise level in hospitals is around 65 decibels), the uneasiness of the patient, difficulties concentrating and understanding abilities may extend the time required (21).

As it is not possible to reduce the information given to patients, it is necessary to make the documents more readable. One of the methods applied in our country is not to give general information about surgical and anaesthesia methods, but to prepare intervention-specific sheets.

Another result from the studies about making ICD more readable is the changes that have to be made in the layout of the documents. The suggestions for this are about the typefont, the rhetoric used and the general statement. For example, some of the suggestions include making the font size 12 or larger, using either Times New Roman or Bookman Old Style, not making all of the letters capital and bold-faced, using short sentences (less than 20 words) and limiting paragraphs to no longer than 10 lines (22).

While referring to the patient, instead of first- or third-person singular, second-person singular should be used; active sentences should be used instead of passive sentences, and instead of medical terms, short and common words from spoken language should be used (23-25).

Another way of informing patients is to support the ICD with visual elements. It has been documented that, in addition to simple drawings and shapes, giving images of surgical intervention and anaesthesia processes via informative leaflets or multimedia means like CD and DVD to the patients does not increase the uneasiness of the patients and actually contributes to the operation being better understood $(25,26)$.

As a result of the studies which aim to organise the IC process and one of its important parts, ICD, in a lot of developed countries, ICD is standard. Looking at the literature, it can be seen that the rate of not reading the ICD has decreased from $69 \%$ to $15 \%-21 \%$ (Table 4$)(5-8,27$ ).

Unfortunately, the lack of studies about this process in our country results in the production of different ICDs for the same procedures by different hospitals, or simply copying a few of the good ones.

As a result, the IC process is considered an informing period which respects the self-determination of the patient and, by doing so, enables the patients to decide safely about the surgical interventions being performed on his/her body. Efforts to improve this process increase the patients' trust in doctors and the healthcare system and will change the impression of the ICD as just 'a document to sign'.

Ethics Committee Approval: Ethics committee approval was received for this study.

Informed Consent: Written informed consent was obtained from patients who participated in this study.

Peer-review: Externally peer-reviewed.

Author contributions: Concept - M.Ö.Ö., M.A.S., İ.Ç.; Design - M.Ö.Ö., İ.Ç., M.A.S.; Supervision - C.Ö.Ç., A.E., E.K.; Resource - M.B.E., N.Ç., B.A.; Materials - B.A., M.A.S., G.B.A.; Data Collection\&/or Processing A.E., M.A.S., İ.Ç.; Analysis\&/or Interpretation - N.Ç., B.A., A.E.; Literature Search - C.Ö.Ç., G.B.A., E.K.; Writing - M.Ö.Ö., G.B.A., M.B.E.; Critical Reviews - M.B. E., G.B.A., E.K.

Conflict of Interest: No conflict of interest was declared by the authors.

Financial Disclosure: The authors declared that this study has received no financial support.

\section{REFERENCES}

1. TTB-UDEK Etik Çalışma Grubu. Aydınlatılmış onam kılavuzu. Available from: http://www.ttb.org.tr/kutuphane/etik_klavuzlar.pdf

2. 1219 sayılı Tababet ve Şuabatı Sanatlarının Tarz-1 İcrasına Dair Kanun (1928). (Madde 70) Available from: http://www.mevzuat.adalet.gov.tr/ $\mathrm{html} / 451 . \mathrm{html}$ 
3. Sağlık Bakanlığı Hasta Hakları Uygulama Yönergesi. Available from: http://sbu.saglik.gov.tr/hastahaklari/yeniyonerge.html

4. Türk Tabipleri Birliği Hekimlik Meslek Etiği Kuralları, Madde 26: Aydınlatılmış onam. Available from: www.ttb.org.tr/mevzuat/index. php? option=com_content.

5. Akkad A, Jackson C, Kenyon S, Dixon-Woods M, Taub N, Habiba M. Patients' perceptions of written consent: A questionnaire study. $B M J$ 2006;333:528-9. [CrossRef]

6. Cassileth BR, Zupkis RV, Sutton-Smith K, March V. Informed Consent -- Why are its goal imperfectly realized? N Engl J Med 1980;302:896900. [CrossRef]

7. Lavelle-Jones C, Byrne DJ, Rice P, Cuschieri A. Factors affecting quality of informed consent. BMJ 1993;306:885-90. [CrossRef]

8. Vila JJ, Jiménez FJ, Iñarrairaegui M, Prieto C, Nantes O, Borda F. Informed consent document in gastrointestinal endoscopy: understanding and acceptance by patients. Rev Esp Enferm Dig 2006;98:101-11. [CrossRef]

9. Aabakken L, Baasland I, Lygren I, Osnes M. Development and evaluation of written patient infrmation for endoscopic procedures. Endoscopy 1997;29:23-6. [CrossRef]

10. Krupp W, Spanehl O, Laubach W, Seifert V. Informed consent in neurosurgery: patients' recall of preoperative discussion. Acta Neurochir (Wien) 2000;142:233-9. [CrossRef]

11. Godwin Y. Do they listen? A review of information retained by patients following consent for reduction mammoplasty. Br J Plast Surg 2000;53:121 -5. [CrossRef]

12. Byrne DJ. Napier A, Cuschieri A. How informed is signed consent? BMJ 1988;296:839-40. [CrossRef]

13. Lynöe N1, Sandlund M, Dahlqvist G, Jacobsson L. Informed consent:study of quality of information given to patients in a clinical trial. BMJ 1991;303:610-3. [CrossRef]

14. Erdoğan N, Kara M, Hizal A, Hizal SA. Informed concent: practice and issues in terms of medical law. Erciyes Med J 2011;33:165-170.

15. Ghulam AT, Kessler M, Bachmann LM, Haller U, Kessler TM. Patient's satisfaction with the preoperative informed consent procedure: A multicenter questionnaire survey in Switzerland. Mayo Clin Proc 2006;81:307-12. [CrossRef]
16. Ahmed SA, Dewedar S. Obstetric patient perceptions of written consent forms: A middle east hospital study. IJAR 2011;3:473-76.

17. Coyne CA, Xu R, Raich P, Plomer K, Dignan M, Wenzel LB. Randomized controlled trial of an easy to read informed consent statement for clinical trial participation: a study of the Eastern Cooperative Oncology Group. J Clin Oncol 2003;21:836-42. [CrossRef]

18. Berger O, Grønberg BH, Sand K, Kaasa S, Loge JH. The length of consent documents in oncological trials is doubled in twenty years. Ann Oncol 2009;20:379-85. [CrossRef]

19. Ivarsson B, Larsson S, Lührs C, Sjöberg T. Extended written pre-operative information about possible complications at cardiac surgery - do the patients want to know? Eur J Cardiothorac Surg 2005;28:407-14. [CrossRef]

20. Saracaloğlu AS, Dedebali NC, Karasakaloğlu N. Sekizinci sınıf ögrencilerinin sessiz okuma hızları ve okuduğunu anlama düzeyleri, $A h i$ Evran Üniversitesi Eğitim Fakültesi Dergisi 2011;12:177-93.

21. Gürültü kontrol çalışmaları, Temmuz 2010. T.C. Çevre ve Orman Bakanlığı, Çevre Yönetimi Genel Müdürlüğü, Ankara. Available from: http://gurultu.cevreorman.gov.tr/ gurultu/ Files/ Gurultu/ Dokumanlar/ Gürültü Kontrol Çalışmaları.pdf.

22. Sand K, Eik-Nes NL, Loge JH. Readibility of informed consent documents (1987-2007) for clinical trials: a linguistic analysis. $J$ Empir Res Hum Res Ethics 2012;7:67-78. [CrossRef]

23. Ezeome ER, Chuke PI, Ezeome IV. Contents and readability of currently used surgical/procedure informed consent forms in Nigerian tertiary health institutions. Niger J Clin Pract 2011;14:311-17. [CrossRef]

24. Küçüker H. Are informed and consent forms sufficient in patients who undergone surgical interventions? Nobel Med 2012;8:40-43.

25. Salzwedel C, Petersen C, Blanc I, Koch U, Goetz AE, Schuster M. The effect of detailed, video-assisted anesthesia risk education on patient anxiety and the duration of the preanesthetic interview: A randomized controlled trial. Anesth Analg 2008;106:202-9. [CrossRef]

26. Gillies MA, Baldwin FJ. Do patient information booklets increase perioperative anxiety? Eur J Anaesthesiol 2001;18:620-2. [CrossRef]

27. Rosique I, Pérez-Cárceles MD, Romero-Martín M, Osuna E, Luna A. The use and usefulness of information for patients undergoing anaesthesia. Med Law 2006;25:715-27. 